\title{
THE EFFECT OF CO DONOR HEMIN ON THE ANTIOXIDANT AND OSMOPROTECTIVE SYSTEMS STATE IN ARABIDOPSIS OF A WILD-TYPE AND MUTANTS DEFECTIVE IN JASMONATE SIGNALING UNDER SALT STRESS
}

\author{
M. A. SHKLIAREVSKYI ${ }^{1}$, Yu. E. KOLUPAEV $V^{1,2 \bowtie, ~ T . ~ O . ~ Y A S T R E B ~}{ }^{1}$, \\ Yu. V. KARPETS 1 , A. P. DMITRIEV ${ }^{3}$ \\ ${ }^{1}$ Dokuchaev Kharkiv National Agrarian University, Ukraine; \\ ${ }^{2}$ Karazin Kharkiv National University, Ukraine; \\ ${ }^{3}$ Institute of Cell Biology and Genetic Engineering, \\ National Academy of Sciences of Ukraine, Kyiv; \\ 凶e-mail: plant.biology.knau@gmail.com
}

Received: 6 December 2020; Accepted: 17 May 2021

The role of the gasotransmitter carbon monoxide (CO) in signaling and adaptive processes in plants has been studied insufficiently. There are indirect data indicating jasmonate signaling participation in realization of CO effects, but the possible connection between carbon monoxide and jasmonate signaling during plant adaptation to salt stress remains unclear. We studied the carbon monoxide donor hemin effect on the Arabidopsis of a wild-type (Col-0) and defective in jasmonate signaling coil and jinl mutants response to the salt stress. Arabidopsis thaliana 4-week-old plants were grown on a modified Hoagland's medium. Plants were incubated for $24 \mathrm{~h}$ in usual or $2 \mu \mathrm{M}$ hemin containing culture medium, then transferred to $150 \mathrm{mM} \mathrm{NaCl}$ containing media and incubated for $24 \mathrm{~h}$ before the medium was replaced with the usual one. It was shown that salt stress caused water deficiency and superoxide dismutase and catalase activity decrease in the plants of all three genotypes. Treatment with $2 \mu M$ hemin stabilized the levels of catalase activity and photosynthetic pigments and increased guaiacol peroxidase activity in a wild-type, but not in coil and jin1 mutant plants after stress induction. Treated with hemin wild-type Arabidopsis plants accumulated more proline and sugars in response to stress than treated coil and jin1 mutants. It was concluded that jasmonate signaling can be involved in adaptive processes induced by exogenous carbon monoxide.

Keywords: carbon monoxide, jasmonate signaling, salt resistance, wild type Arabidopsis thaliana, coil and jin1 mutants, antioxidant enzymes, pigments, proline.

A t present, the participation of gasotransmitters (gaseous molecules that perform signaling functions) in biochemical and physiological processes of not only animals [1] but also plants [2, 3] is being intensively studied. The main gasotransmitters include carbon monoxide (CO), nitrogen oxide (NO), and hydrogen sulfide $\left(\mathrm{H}_{2} \mathrm{~S}\right)$ [4-6]. Recently, phytophysiologists have also focused on the signaling functions of methane [7] and gaseous hydrogen [8]. Gasotransmitters are characterized by the absence of specific receptors, the presence of common targets of action, and multilevel functional interaction with each other [9]. It is largely due to the presence of common sites for interaction of gasotransmitters with protein targets. These sites can be primarily thiol groups and active sites containing heme [2]. Other ways of gasotransmitters functional interaction are associated with their influence on synthesis of each other. For plant objects, data were obtained on the effect of $\mathrm{CO}$ on $\mathrm{NO}$ synthesis, as well as on the enhancement of CO synthesis under the action of $\mathrm{H}_{2} \mathrm{~S}$ and vice versa [2]. In this regard, the same physiological effects, for example, induction of protective responses that determine resistance

(C) 2021 Shkliarevskyi M. A. et al. This is an open-access article distributed under the terms of the Creative Commons Attribution License, which permits unrestricted use, distribution, and reproduction in any medium, provided the original author and source are credited. 
to stressors, can be achieved using different gasotransmitters.

CO is still one of the poorly studied gasotransmitters of plant cells [2,3]. To date, the effects of enhancing its synthesis in plants have been described under the action of stressors of various natures [10-12]. Also, the effects of increasing plant resistance to various adverse influences are shown when treated with gaseous $\mathrm{CO}$ or its donors - hematin and hemin [13-15]. The action of exogenous CO on plant salt tolerance has been studied only on cultivated grains and some legumes [16-18]. It has been shown that the gaseous $\mathrm{CO}$ and hematin enhanced plant defense reactions such as increased expression of genes encoding antioxidant enzymes $[17,18]$ and accumulation of proline [19]. However, in general, the influence of $\mathrm{CO}$ donors on the functioning of plant protective systems under salt stress has been poorly studied. In particular, the effect of exogenous $\mathrm{CO}$ on the salt tolerance of Arabidopsis thaliana plants, one of the main model objects of experimental plant biology, remains unexplored.

Gasotransmitters are in close relation to the plant hormone signaling network. On the one hand, they are involved in the transduction of phytohormone signals into genetic apparatus [20]. On the other, changes in the content of gasotransmitters can affect the hormonal complex [21, 22], in particular, the content of jasmonates [21]. Thus, a rise in the amount of latter in plants was recorded under the influence of exogenous NO [21] and CO [23]. The action of hyperthermia on tobacco plants caused an increase in CO synthesis, which, in turn, increased the formation of jasmonic acid. As a result, the jasmonate signaling transcription factor NtMYC2a was activated that led to the activation of expression of the putrescine-N-methyltransferase gene NtPMT1 and, ultimately, to the thermal-induced enhancement of nicotine synthesis [23].

JIN1/MYC2 transcription factor controls the expression of genes induced not only by jasmonate but also by abscisic acid [24, 25]. This protein is considered as one of the key ones in stress signaling, in particular, during the development of plant defense responses to drought and salinity [24]. Based on the data obtained by bioinformatics methods, it was concluded that the MYC family genes are involved in the transduction of NO signals [26]. Our data on an increase in the salt resistance of Arabidopsis wild-type plants under the influence of $\mathrm{NO}$ and $\mathrm{H}_{2} \mathrm{~S}$ donors and a very weak manifestation of such effects in mutants jinl and coil, defective in jasmonate signaling, indicates the involvement of components of this signaling in the implementation of stress-protective effects of gasotransmitters NO and $\mathrm{H}_{2} \mathrm{~S}$ [27]. In general, jasmonic acid and its derivatives are considered as one of the important links in plant adaptation to abiotic and biotic stress factors $[28,29]$. In particular, they are involved in the regulation of such important systems as antioxidant and osmoprotective [30].

In connection with the data on the role of jasmonic acid and genes controlled by it in the manifestation of $\mathrm{CO}$ effects under heat stress [23], as well as data on the jasmonate signaling involvement in the realization of stress-protective effects of other gasotransmitters $\left(\mathrm{NO}, \mathrm{H}_{2} \mathrm{~S}\right)$ [27], it was of interest to study the effect of the $\mathrm{CO}$ donor hemin on the salt tolerance of Arabidopsis plants defective in jasmonate signaling. For this, we used plants of the coil (mutant for the gene encoding the COI1 protein involved in the removal of repressor proteins of jasmonate signaling transcription factors) and jinl (a mutant defective in the gene encoding the JIN1/ MYC2 transcription factor) genotypes.

It is well known that high concentrations of $\mathrm{Na}^{+}$ and/or $\mathrm{Cl}^{-}$in the environment cause osmotic stress in plants due to a sharp drop in the water potential in root habitat [31]. The effect of osmotic stress in plants in response to an increase in salt concentration in the medium leads to a decrease in stomatal conductance. As a result, entry of $\mathrm{CO}_{2}$ into cells and functioning of electron transport chain in chloroplasts are disrupted, which leads to an increase in the ROS formation. Development of oxidative stress is also facilitated by a salinity-induced change in $\mathrm{pH}$ of cytoplasm, leading to an increase in reactions of non-enzymatic ROS formation. In this regard, activation of antioxidant system and accumulation of compatible osmolytes [31], primarily proline and sugars, which also have antioxidant properties, are considered the key defense mechanisms of plants in response to salt stress. The objectives of the work were to compare the functioning of the enzymatic antioxidant and osmoprotective systems of wild-type Arabidopsis plants (Col-0) and mutants coi1 and jin1 above under the action of salt stress and the CO donor hemin.

\section{Materials and Methods}

For experiments, we used 4-week-old plants Arabidopsis thaliana L. wild-type (Col-0) and mutant lines coil and jinl whose seeds were kindly pro- 
vided by prof. J.-M. Neuhaus (Nashatel University, Switzerland). Plants were grown in aquatic culture on Hoagland medium with modifications [32] at a temperature of $22 / 16^{\circ} \mathrm{C}$ (day/night), illumination of 6000 lux, and a 10-h photoperiod [29].

CO donor hemin (Sigma-Aldrich, USA) was inserted into the culture medium, and plants were incubated on it for $24 \mathrm{~h}$. After that, they were transferred to a nutrient mixture without hemin but with the addition of $150 \mathrm{mM} \mathrm{NaCl}$. After 24-h incubation of plants in the presence of sodium chloride, the medium was replaced with the usual one. In preliminary experiments, it was found that such an action of salt did not lead to a loss of turgor but caused an increase in the indicator of water deficit and a decrease in the chlorophyll content in the leaves with further growth of plants on medium without $\mathrm{NaCl}$.

The optimal concentration of hemin $(2 \mu \mathrm{M})$, which most effectively prevents the development of water deficiency and a decrease in the content of chlorophylls in leaves after exposure to salt stress, was established in preliminary experiments (results not shown).

For all biochemical analyzes, developed rosette leaves were used. All parameters, except for the content of photosynthetic pigments, were determined immediately after the end of the stress exposure.

Water deficiency was estimated by saturation of intact leaves with water and expressed as a percentage of the total water content in a state of complete saturation [33].

Activities of superoxide dismutase (SOD), catalase, and guaiacol peroxidase were determined by methods described in detail earlier [30]. The weighed leaves were homogenized in the cold $0.15 \mathrm{M} \mathrm{K}, \mathrm{Na}-$ phosphate buffer ( $\mathrm{pH}$ 7.6), containing $0.1 \mathrm{mM}$ EDTA and $1 \mathrm{mM}$ dithiothreitol. For analysis, the supernatant was used after centrifuging the homogenate at $8000 \mathrm{~g}$ on an MPW 350R centrifuge (MedInstruments, Poland) for $10 \mathrm{~min}$ at $4^{\circ} \mathrm{C}$. The activity of the cytosolic SOD (EC 1.15.1.1) was determined at pH 7.6 using a method based on the enzyme's ability to compete with nitroblue tetrazolium for superoxide anions formed due to the aerobic interaction of NAD·H and phenazine methosulfate. The catalase (EC 1.11.1.6) activity was analyzed at $\mathrm{pH} 7.0$ by the amount of decomposed hydrogen peroxide per unit time. The activity of guaiacol peroxidase (EC 1.11.1.7) was determined at $\mathrm{pH} 6.2$ of the reaction mixture, using guaiacol as the reducing agent. SOD and guaiacol peroxidase activity was expressed as arbitrary units/(g dry weight·min), catalase activity - as $\mu \mathrm{M} \mathrm{H}_{2} \mathrm{O}_{2}$ /(g dry weight·min).

The proline content in the leaves was analyzed by the method of Bates et al. [34] and expressed in $\mu \mathrm{mol} / \mathrm{g}$ dry weight. The total amount of sugars was analyzed by the Morris-Rohe method using an anthrone reagent [35] with our slight modifications [36].

Photosynthetic pigments were analyzed 2 days after the action of salt on plants. As preliminary experiments showed, it was precisely at such a time after stressful exposure that the most noticeable decrease in the content of chlorophyll in the leaves was observed. Pigments were extracted from leaves with ethanol and the content was determined spectrophotometrically [37]. Their amount was expressed in mg/g dry weight.

Independent experiments were repeated three times. The results were processed by the dispersion method. The figures and the table show the mean values and their standard errors. Except as otherwise specified, the differences between the variants are discussed, which are significant at $P \leq 0.05$.

\section{Results and Discussion}

Under the influence of $\mathrm{NaCl}$, the water deficit in tissues of Arabidopsis leaves of all three genotypes was more than doubled (Fig. 1). Treatment of wild-type plants with the CO donor hemin before salt stress markedly reduced its manifestation under stress conditions. At the same time, this effect did not appear in both mutants defective in jasmonate signaling. It should be noted that the emergence of water deficiency in plants under an increase in salt concentration in the root solution manifests itself rather quickly and leads to secondary negative consequences, in particular, to stomata closure, limitation of $\mathrm{CO}_{2}$ intake, development of oxidative stress, and growth inhibition [38]. Thus, the decrease in the water deficit under salt stress in wild-type plants under the influence of the $\mathrm{CO}$ donor indicates an increase in the development of adaptive responses.

One of the integral indicators of plant resistance to stressors, in particular, salinity, is the preservation of the photosynthetic pigments pool after exposure to an unfavorable factor [39]. Under the conditions of our experiments, 2 days after exposure to $150 \mathrm{mM}$ $\mathrm{NaCl}$, the content of chlorophylls significantly decreased in all three genotypes (Table). The treatment with hemin partially counteracted the decrease in chlorophyll $a$ content under salt stress but did not 


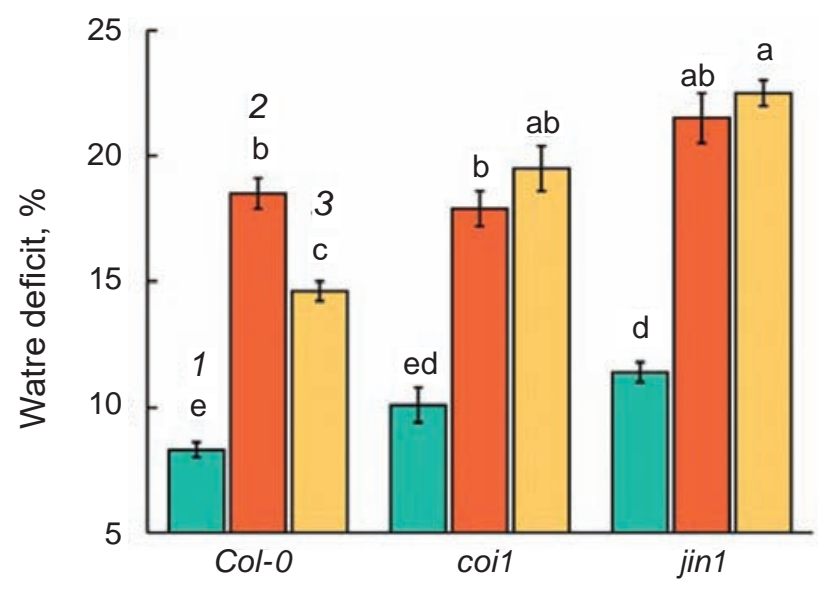

Fig. 1. Water deficiency of Arabidopsis leaves under the action of $\mathrm{NaCl}$ and hemin (CO donor): 1 control; 2 - NaCl (150 mM); $3-\mathrm{NaCl}(150 \mathrm{mM})+$ hemin $(2 \mu M)$. The same Latin letters denote quantities between which differences are not reliable for $P \leq 0.05$

affect chlorophyll $b$ content. At the same time, no significant changes in the content of chlorophylls in coil and jin1 plants subjected to salt stress were observed under the treatment with the CO donor. These results suggest the possibility of jasmonatedependent interaction of CO with pathways of chlorophyll a biosynthesis. However, the effect of hemin as an inductor of heme oxygenase on chlorophyll synthesis may be associated not so much with the effects of $\mathrm{CO}$ as with the simultaneous increase in the formation of biliverdin IX $\alpha$. There are data in the literature on the involvement of heme oxygenase 1 (HO1) as an enzyme that catalyzes the conversion of heme with the formation of biliverdin IX $\alpha$ in the metabolism of tetrapyrroles, especially chlorophyll [40]. On the other hand, jasmonate is also involved in regulating chlorophyll metabolism [41], and under stressful conditions, it can contribute to the preservation of its pool [42]. It is quite natural that special studies are needed to conclude on the role of the possible functional interaction of $\mathrm{CO}$ and components of jasmonate signaling in the regulation of chlorophyll metabolism under normal and stressful conditions.

The content of carotenoids under the salt stress influence decreased in leaves of wild-type and coi1 mutant; in plants of the jinl genotype, this effect was manifested at the trend level (Table). Hemin treatment led to a significant increase in the carotenoid content under stress conditions only in Col-0 plants. In mutants defective in jasmonate signaling, this effect was less pronounced. It is possible that the functional relationship between $\mathrm{CO}$ and jasmonate may be involved in the metabolism of carotenoids.

In general, under salt stress, a noticeable positive effect, determined by the level of water deficit and the content of photosynthetic pigments, was exerted by the $\mathrm{CO}$ donor treatment on wild-type

Content of chlorophyll and carotenoids ( $\mathrm{mg} / \mathrm{g} \mathrm{d.w.)} \mathrm{in} \mathrm{leaves} \mathrm{of} \mathrm{Arabidopsis}$

\begin{tabular}{|c|c|c|c|c|}
\hline Option & Chlorophyll $a$ & Chlorophyll $b$ & Chlorophylls $a+b$ & Carotenoids \\
\hline \multicolumn{5}{|c|}{ Col-0 } \\
\hline Control & $14.22 \pm 0.27^{a}$ & $4.18 \pm 0.11^{\mathrm{a}}$ & $18.40 \pm 0.29^{a}$ & $2.49 \pm 0.07^{\mathrm{ab}}$ \\
\hline $\mathrm{NaCl}(150 \mathrm{mM})$ & $10.72 \pm 0.22^{\mathrm{c}}$ & $2.91 \pm 0.11^{\mathrm{b}}$ & $13.63 \pm 0.25^{c}$ & $1.99 \pm 0.06^{\mathrm{b}}$ \\
\hline $\begin{array}{l}\operatorname{NaCl}(150 \mathrm{mM}) \\
+ \text { hemin }(2 \mu \mathrm{M})\end{array}$ & $12.25 \pm 0.20^{\mathrm{b}}$ & $\begin{array}{c}2.65 \pm 0.10^{\mathrm{bc}} \\
\text { coil }\end{array}$ & $14.90 \pm 0.22^{b}$ & $2.71 \pm 0.09^{a}$ \\
\hline Control & $14.89 \pm 0.26^{a}$ & $4.32 \pm 0.12^{\mathrm{a}}$ & $19.21 \pm 0.29^{a}$ & $2.69 \pm 0.09^{a}$ \\
\hline $\mathrm{NaCl}(150 \mathrm{mM})$ & $10.72 \pm 0.24^{c}$ & $2.64 \pm 0.08^{\mathrm{bc}}$ & $13.36 \pm 0.26^{\mathrm{cd}}$ & $2.00 \pm 0.10^{b}$ \\
\hline $\begin{array}{l}\operatorname{NaCl}(150 \mathrm{mM}) \\
+ \text { hemin }(2 \mu \mathrm{M})\end{array}$ & $11.39 \pm 0.23^{\mathrm{bc}}$ & $\begin{array}{c}2.18 \pm 0.12^{\mathrm{c}} \\
\text { jinl }\end{array}$ & $13.57 \pm 0.26^{c}$ & $2.55 \pm 0.15^{\mathrm{ab}}$ \\
\hline Control & $14.70 \pm 0.25^{\mathrm{a}}$ & $4.38 \pm 0.09^{\mathrm{a}}$ & $19.08 \pm 0.27^{\mathrm{a}}$ & $2.21 \pm 0.09^{b}$ \\
\hline $\mathrm{NaCl}(150 \mathrm{mM})$ & $9.66 \pm 0.22^{\mathrm{d}}$ & $1.95 \pm 0.12^{\mathrm{c}}$ & $11.61 \pm 0.25^{\mathrm{d}}$ & $2.10 \pm 0.10^{\mathrm{b}}$ \\
\hline $\begin{array}{l}\text { NaCl }(150 \mathrm{mM}) \\
+ \text { hemin }(2 \mu \mathrm{M})\end{array}$ & $10.34 \pm 0.24^{\mathrm{cd}}$ & $1.89 \pm 0.11^{\mathrm{c}}$ & $12.23 \pm 0.26^{\mathrm{d}}$ & $2.45 \pm 0.12^{\mathrm{ab}}$ \\
\hline
\end{tabular}

\footnotetext{
*The same Latin letters denote quantities whose differences are not reliable when $P \leq 0.05$
} 
plants, the similar effect of exogenous $\mathrm{CO}$ on coi1 and jin1 plants was less pronounced.

As already noted, one of the key protective systems involved in the plants adaptation to stressors of various natures, including salt stress and cross action of unfavorable factors, is the antioxidant system $[43,44]$. In further experiments, the influence of the CO donor on the state of the enzymatic antioxidant system of Arabidopsis was evaluated under salt stress conditions. The SOD activity in control in jin1 plants was lower than in wild-type and coi1 genotype plants (Fig. 2, A), which is apparently due to genetics and is consistent with the results obtained in other series of experiments [27]. Incubation of plants of all three studied genotypes on a medium with $150 \mathrm{mM} \mathrm{NaCl}$ caused a decrease in SOD activity (Fig. 2, A). Hemin treatment did not significantly affect the enzyme activity in wild-type plants and coil mutant. At the same time, in jinl plants treated with $\mathrm{CO}$ donor, there was a slight but significant increase in SOD activity at $P \leq 0.05$.

Catalase activity in plant leaves of different genotypes Col-0 and coil, grown under normal conditions, differed insignificantly, while in jinl it was slightly lower. Under the influence of salt stress, it also decreased in plants of all genotypes (Fig. 2, B). Preincubation of plants in the presence of hemin completely prevented this effect of salt stress in wildtype plants, but not in coi1 and jinl plants.

Under normal conditions, the activity of guaiacol peroxidase in Col-0 plants was higher than in mutants defective in jasmonate signaling (Fig. 2, C). Salt stress did not significantly affect the activity of this enzyme in all three genotypes. Treatment with the CO donor caused an increase in guaiacol peroxidase activity under salt stress in wild-type plants, but not in mutants defective in jasmonate signaling genes.

The proline content in Arabidopsis plants of different genotypes did not differ significantly (Fig. 3, A). Salt stress in all studied samples caused an increase in the proline content in leaves by 3.5-4.0 times. Pretreatment with hemin of wild-type plants significantly enhanced the effect of proline accumulation under conditions of salt stress. At the same time, in mutants coil and jinl, exposure to the CO donor did not cause changes in the accumulation of proline under salt stress (Fig. 3, A).

Under normal conditions, the content of sugars in leaves of wild-type plants and jin1 plants was almost the same, while in coil plants it was slightly
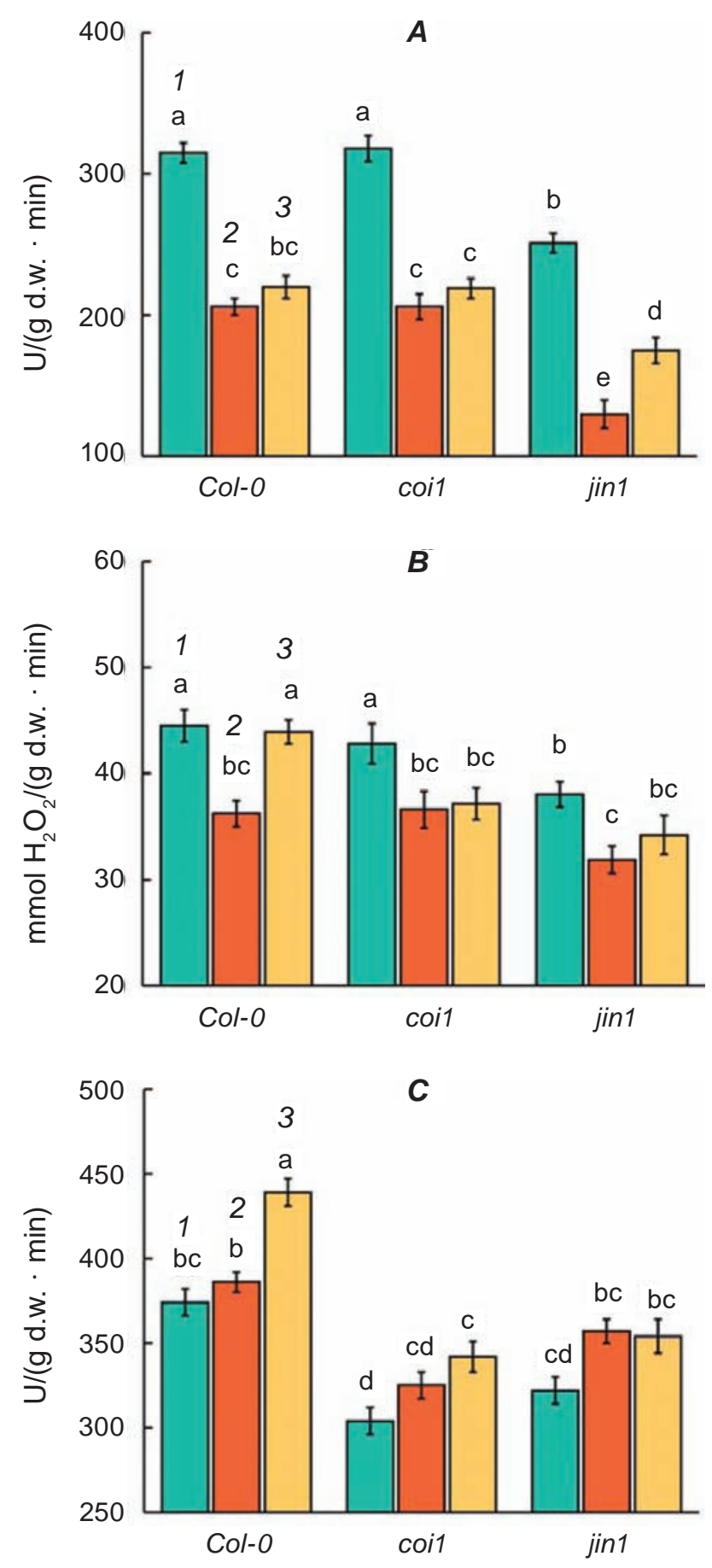

Fig. 2. Activity of SOD (A), catalase (B) and guaiacol peroxidase $(\boldsymbol{C})$ in Arabidopsis leaves under the action of NaCl and hemin (CO donor): 1 - control; 2 $\mathrm{NaCl}(150 \mathrm{mM}) ; 3-\mathrm{NaCl}(150 \mathrm{mM})+$ hemin $(2 \mu \mathrm{M})$. The same Latin letters denote quantities between which differences are not reliable for $P \leq 0.05$

higher, although this difference was not significant at $P \leq 0.05$ (Fig. 3, B). After salt stress, an increase in the amount of sugars in leaves of plants of all studied 

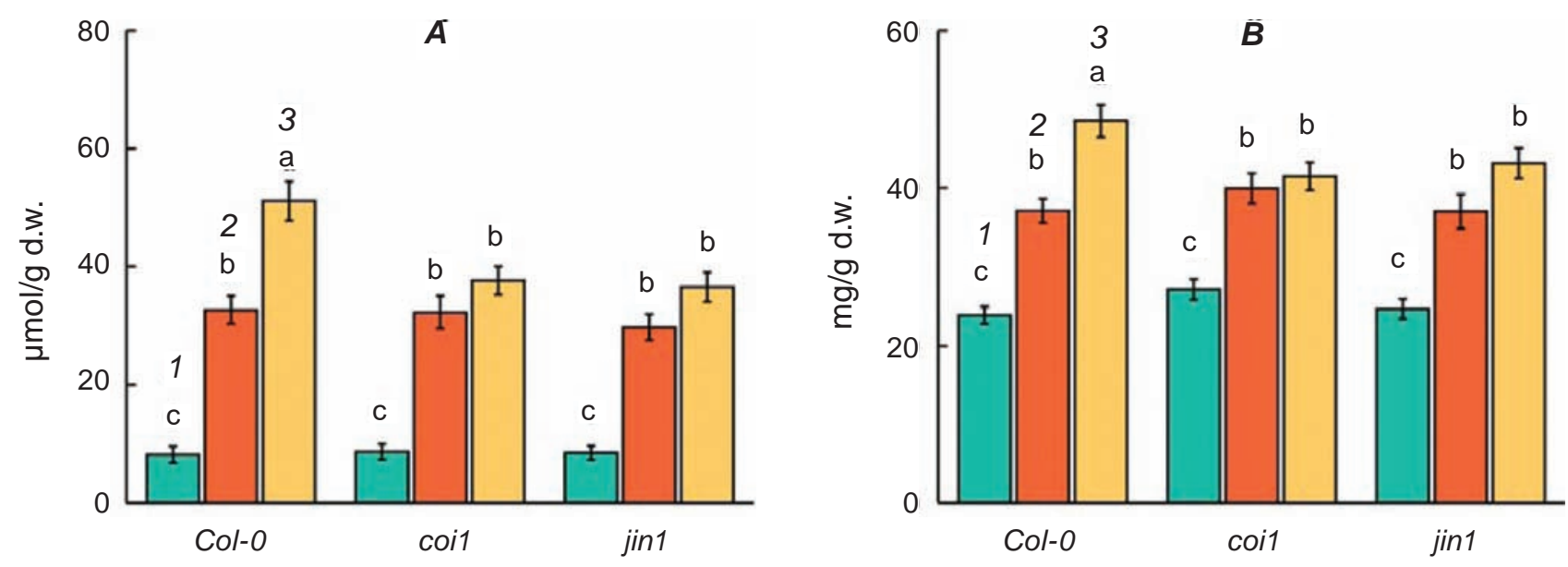

Fig. 3. Proline (A) and sugars (B) contents in leaves of Arabidopsis under the action of NaCl and hemin (CO donor): 1 - control; $2-\mathrm{NaCl}(150 \mathrm{mM}) ; 3-\mathrm{NaCl}(150 \mathrm{mM})+$ hemin $(2 \mu \mathrm{M})$. The same Latin letters denote quantities between which differences are not reliable for $P \leq 0.05$

genotypes was noted. Under the influence of the CO donor, the accumulation of sugars in wild-type plants increased under the action of salt stress. In mutants defective in jasmonate signaling, this effect was not observed (Fig. 3, $B$ ).

The results indicating the enhancement of protective systems functioning in the wild-type Arabidopsis plants upon their treatment with the CO donor before salt stress are consistent with a number of data obtained for other species. Thus, it was shown that, in wheat plants, exogenous CO under salt stress increased the expression of $\Delta^{1}$-pyrroline-5-carboxylate synthase gene and weakened the expression of proline dehydrogenase gene, which led to the accumulation of endogenous proline [45]. In wheat seedlings under strong salt stress, treatment with an aqueous solution of CO prevented the development of programmed death of root cells, reduced the activity of NADPH oxidase, and increased the expression of the Mn SOD gene [17]. Also, it was found that hematin treatment caused an increase in the accumulation of proline and sugars, as well as an increase in the activity of SOD, catalase, ascorbate peroxidase, and glutathione reductase in Cassia oltusifolia under conditions of salt stress [13]. In our experiments, there was no increase in SOD activity in wild type Arabidopsis and coil plants under salt stress under the influence of the CO donor (Fig. 2, A). This may be due to plant species and/or experimental conditions. It is noteworthy, however, that hemin treatment caused a slight increase in SOD activity in jinl plants. It should be noted that in this genotype un- der salt stress there was a stronger decrease in the activity of this enzyme than in wild-type and coi1 plants. It is possible that exogenous CO could partially induce protective systems in jin1 plants, which could indirectly contribute to the maintenance of SOD activity. It is quite natural that our results do not give grounds to exclude the presence of $\mathrm{CO}$ signaling pathways that are not associated with the components of jasmonate signaling. In general, the pronounced positive effect of hemin treatment was manifested only in wild-type Arabidopsis plants. This treatment promoted the stabilization of catalase activity, an increase in the activity of guaiacol peroxidase, and the accumulation of proline and sugars (Fig. 2, 3).

At the same time, in the mutant for the gene encoding the COI1 protein (involved in the removal of repressor proteins of jasmonate signaling transcription factors), as in plants defective in the gene encoding one of the main transcription factors of jasmonate signaling (JIN1/MYC2), under the hemin influence, a significant increase in salt tolerance was not noted. The treatment of such plants with the CO donor did not cause the effect of enhancing the work of the enzymatic antioxidant system (Fig. 2) and additional accumulation of osmolytes (Fig. 3) under salt stress. This effect of the CO donor on the accumulation of proline and sugars in wild-type plants was especially pronounced. The compatible osmolytes proline and sugars play a multifunctional role under salt stress. Accumulating in large quantities, they act not only as osmolytes and membrane-protective com- 
pounds but also as antioxidants capable of binding free radicals [44]. Their accumulation in wild-type Arabidopsis plants treated with CO donor under salt stress can compensate for the absence of the effect of increasing SOD activity [46, 47], which was observed in our experiments (Fig. 2).

Thus, the results obtained indicate the involvement of the jasmonate signaling components in the implementation of stress-protective effects of exogenous carbon monoxide. Undoubtedly, the differences in response to an action of the CO donor in wildtype plants and jasmonate signaling mutants do not provide grounds for concluding that the COI1 and JIN1/MYC2 proteins are directly involved in CO signal transduction. For more definite conclusions about the mechanisms of participation of jasmonate signaling proteins in the implementation of the CO action, special studies are needed. It is possible that the role of COI1 and JIN1/MYC2 proteins under the exogenous $\mathrm{CO}$ action is due to the ability of this gasotransmitter to induce the synthesis of jasmonic acid [23]. This effect was recorded in tobacco plants. However, it cannot be ruled out that certain protein components of jasmonate signaling under the action of CO are regulated not by jasmonic acid itself, but by other signaling mediators. JIN1/MYC2 protein has recently been considered as a kind of hub in the transduction of signals not only for jasmonate, but also ABA [24, 25], and probably also $\mathrm{NO}$ and $\mathrm{H}_{2} \mathrm{~S}$ [27, 29].

So, the marked leveling of defense reactions induced by the CO donor in Arabidopsis mutants, which are defective in two key proteins of jasmonate signaling, recorded in our experiments, indicates the involvement of this signaling in the implementation of CO action. Special studies are needed to explain the mechanisms of jasmonate signaling participation in $\mathrm{CO}$ physiological effects in plants under salt stress.

Conflict of interest. The authors have completed the Unified Conflicts of Interest form at http:// ukrbiochemjournal.org/wp-content/uploads/2018/12/ coi_disclosure.pdf and declare no conflict of interest.

Funding. The scientific manuscript was made within the research work "Mechanisms of induction of components of plants' stress-protective system" (state registration number 0117U002514).

\section{ВПЛИВ ДОНОРА СО ГЕМІНУ НА СТАН АНТИОКСИДАНТНОЇ ТА ОСМОПРОТЕКТОРНОЇ СИСТЕМ АРАБІДОПСИСУ ДИКОГО ТИПУ І МУТАНТІВ ЗА ЖАСМОНАТНИМ СИГНАЛІНГОМ ЗА ДІЇ СОЛЬОВОГО СТРЕСУ}

\author{
М. А. Шкляревський, Ю. С. Колупаєв ${ }^{1,2 \bowtie, ~}$ \\ T. О. Ястреб \\ О. П. Дмитрієв ${ }^{3}$
}

\author{
${ }^{1}$ Харківський національний аграрний \\ університет ім. В. В. Докучаєва, Україна; \\ ${ }^{2}$ Харківський національний університет \\ ім. В. Н. Каразіна, Україна; \\ ${ }^{3}$ Інститут клітинної біології та генетичної \\ інженерії НАН України, Київ; \\ 凶e-mail: plant.biology.knau@gmail.com
}

Роль газотрансмітера монооксиду вуглецю (CO) в сигнальних та адаптивних процесах у рослин досліджено недостатньо. $€$ непрямі дані щодо участі компонентів жасмонатного сигналінгу в реалізації ефектів СО, однак можливі зв'язки між монооксидом вуглецю i жасмонатним сигналінгом за адаптації рослин до сольового стресу дотепер не вивчалися. У роботі оцінено реакцію на сольовий стрес рослин арабідопсису дикого типу (Col-0) та мутантів coi1 i jinl, дефектних за жасмонатним сигналінгом, за їх обробки геміном - донором СО. У експериментах використовували чотиритижневі рослини Arabidopsis thaliana, вирощені на модифікованому середовищі Хогланда. Рослини інкубували 24 год у звичайному або гемінвмісному (2 мкМ) культуральному середовищі, після чого переносили у $\mathrm{NaCl-вмісне} \mathrm{(150} \mathrm{мМ)} \mathrm{середовище} \mathrm{та} \mathrm{знов}$ інкубували протягом 24 год, надалі середовище замінювали на звичайне. Показано, що сольовий стрес спричинює водний дефіцит та знижує активність супероксиддисмутази і каталази в рослинах усіх трьох генотипів. За дії геміну виявлено стабілізацію активності каталази та вмісту фотосинтетичних пігментів, а також підвищення активності пероксидази гваяколу в підданих стресу рослинах дикого типу, але не в мутантних coi1 та jinl. Оброблені геміном рос- 
лини арабідопсису дикого типу накопичували більше проліну та цукрів у відповідь на стрес, ніж оброблені мутанти coi1 та jin1. Дійшли висновку, що компоненти жасмонатного сигналінгу можуть бути залучені до адаптивних процесів, індукованих екзогенним монооксидом вуглецю.

К л юч о в $\quad$ слова: монооксид вуглецю, жасмонатний сигналінг, солестійкість, Arabidopsis thaliana дикого типу, coi1 та jin1 мутанти, антиоксидантні ензими, пігменти, пролін.

\section{References}

1. Sukmansky OI, Reutov VP. Gasotransmitters: Physiological Role and Involvement in the Pathogenesis of the Diseases. Usp Fiziol Nauk. 2016; 47(3): 30-58. (In Russian).

2. Jin Q, Cui W, Xie Y, Shen W. Carbon monoxide: A ubiquitous gaseous signaling molecule in plants. In: Lamattina L, Garcia-Mata C (eds). Gasotransmitters in Plants, Signaling and Communication in Plants, Switzerland: Springer International Publishing, 2016: 3-19.

3. Kolupaev YuE, Karpets YuV, Beschasniy SP, Dmitriev AP. Gasotransmitters and their role in adaptive reactions of plant cells. Cytol Genet. 2019; 53(5): 392-406.

4. $\mathrm{He} \mathrm{H}, \mathrm{He} \mathrm{L}$. The role of carbon monoxide signaling in the responses of plants to abiotic stresses. Nitric Oxide. 2014; 42: 40-43.

5. Wang R. Gasotransmitters: growing pains and joys. Trends Biochem Sci. 2014; 39(5): 227-232.

6. Khan MN, Mobin M, Abbas ZK. Nitric oxide and high temperature stress: A physiological perspective. In: Khan MN. et al (ed). Nitric Oxide Action in Abiotic Stress Responses in Plants. Switzerland: Springer International Publishing, 2015: 77-93.

7. Li L, Wei S, Shen W. The role of methane in plant physiology: a review. Plant Cell Rep. 2020; 39(2): 171-179.

8. Chen Y, Wang M, Hu L, Liao W, Dawuda MM, $\mathrm{Li} \mathrm{C}$. Carbon monoxide is involved in hydrogen gas-induced adventitious root development in cucumber under simulated drought stress. Front Plant Sci. 2017; 8: 128.

9. Hancock JT. Hydrogen sulfide and environmental stresses. Environ Exp Bot. 2019; 161: 50-56.

10. Liu Y, Xu S, Ling T, Xu L, Shen W. Heme oxygenase/carbon monoxide system participates in regulating wheat seed germination under osmotic stress involving the nitric oxide pathway. J Plant Physiol. 2010; 167(16): 1371-1379.

11. Wei MY, Chao YY, Kao CH. NaCl-induced heme oxygenase in roots of rice seedlings is mediated through hydrogen peroxide. Plant Growth Regul. 2013; 69(3): 209-214.

12. Verma K, Dixit S, Shekhawat GS, Alam A. Antioxidant activity of heme oxygenase 1 in Brassica juncea (L.) Czern. (Indian mustard) under salt stress. Turk J Biol. 2015; 39: 540-549.

13. Zhang C, Li Y, Yuan F, Hu S, He P. Effects of hematin and carbon monoxide on the salinity stress responses of Cassia obtusifolia L. seeds and seedlings. Plant Soil. 2012; 359(1-2): 85-105.

14. Chen Q, Gong C, Ju X, Zhu Z, Shen W, Shen Z, Cui J. Hemin through the heme oxygenase 1/ ferrous iron, carbon monoxide system involved in zinc tolerance in Oryza sativa L. J Plant Growth Regul. 2018; 37(3): 947-957.

15. Shkliarevskyi MA, Karpets YuV, Kolupaev YuE, Lugovaya AA, Dmitriev AP. Calcium-dependent changes in cellular redox homeostasis and heat resistance of wheat plantlets under influence of hemin (carbon monoxide donor). Cytol Genet. 2020; 54(6): 522-530.

16. Xu S, Sa ZS, Cao ZY, Xuan W, Huang BK, Ling TF, Hu QY, Shen WB. Carbon monoxide alleviates wheat seed germination inhibition and counteracts lipid peroxidation mediated by salinity. J Integr Plant Biol. 2006; 48(10): 11681176.

17. Ling T, Zhang B, Cui W, Wu M, Lin J, Zhou W, Huang J, Shen W. Carbon monoxide mitigates salt-induced inhibition of root growth and suppresses programmed cell death in wheat primary roots by inhibiting superoxide anion overproduction. Plant Sci. 2009; 177(4): 331-340.

18. Xie Y, Ling T, Han Y, Liu K, Zheng Q, Huang L, Yuan X, He Z, Hu B, Fang L, Shen Z, Yang Q, Shen W. Carbon monoxide enhances salt tolerance by nitric oxide-mediated maintenance of ion homeostasis and up-regulation of antioxidant defence in wheat seedling roots. Plant Cell Environ. 2008; 31(12): 1864-1881.

19. Yuan XX, Wang J, Xie YJ, Shen WB. Effects of carbon monoxide on salt tolerance and proline content of roots in wheat seedling. Plant Physiol. Commun. 2009; 45(6): 567-570.

20. Shan C, Wang T, Zhou Y, Wang W. Hydrogen sulfide is involved in the regulation of ascorbate and glutathione metabolism by jasmonic acid in 
Arabidopsis thaliana. Biol Plant. 2018; 62(1): 188-193.

21. Huang X, Stettmaier K, Michel C, Hutzler P, Mueller MJ, Durner J. Nitric oxide is induced by wounding and influences jasmonic acid signaling in Arabidopsis thaliana. Planta. 2004; 218(6): 938-946.

22. Banerjee A, Tripathi DK, Roychoudhury A. Hydrogen sulphide trapeze: Environmental stress amelioration and phytohormone crosstalk. Plant Physiol Biochem. 2018; 132: 46-53.

23. Cheng T, Hu L, Wang P, Yang X, Peng Y, Lu Y, Chen J, Shi J. Carbon monoxide potentiates high temperature-induced nicotine biosynthesis in tobacco. Int J Mol Sci. 2018; 19(1): 188.

24. Ton J, Flors V, Mauch-Mani B. The multifaceted role of ABA in disease resistance. Trends Plant Sci. 2009; 14(6): 310-317.

25. Lackman P, González-Guzmán M, Tilleman S, Carqueijeiro I, Pérez AC, Moses T, Seo M, Kanno Y, Häkkinen ST, Van Montagu MC, Thevelein JM, Maaheimo H, OksmanCaldentey KM, Rodriguez PL, Rischer $\mathrm{H}$, Goossens A. Jasmonate signaling involves the abscisic acid receptor PYL4 to regulate metabolic reprogramming in Arabidopsis and tobacco. Proc Natl Acad Sci USA. 2011; 108(14): 5891-5896.

26. Palmieri MC, Sell S, Huang $X$, Scherf $M$, Werner T, Durner J, Lindermayr C. Nitric oxideresponsive genes and promoters in Arabidopsis thaliana: a bioinformatics approach. J Exp Bot. 2008; 59(2): 177-186.

27. Yastreb TO, Kolupaev YuE, Shkliarevskyi MA, Dmitriev AP. Participation of jasmonate signaling components in the development of Arabidopsis thaliana's salt resistance induced by $\mathrm{H}_{2} \mathrm{~S}$ and NO donors. Russ J Plant Physiol. 2020; 67(5): 827-834.

28. Babenko LM, Shcherbatiuk MM, Skaterna TD, Kosakivska IV. Lipoxygenases and their metabolites in formation of plant stress tolerance. Ukr Biochem J. 2017; 89(1): 5-21.

29. Kolupaev YuE, Yastreb TO. Jasmonate signaling and plant adaptation to abiotic stressors (Review). Appl Biochem Microbiol. 2021; 57(1): 1-19.

30. Yastreb TO, Kolupaev YuE, Shvidenko NV, Dmitriev AP. Action of methyl jasmonate and salt stress on antioxidant system of Arabidopsis plants defective in jasmonate signaling genes. Ukr Biochem J. 2018; 90(5): 50-59.
31. Rozentsvet OA, Nesterov VN, Bogdanova ES. Structural, physiological, and biochemical aspects of salinity tolerance of halophytes. Russ J Plant Physiol. 2017; 64(4): 251-265.

32. Semchuk NM, Vasylyk YV, Lushchak OV, Lushchak VI. Effect of short-term salt stress on oxidative stress markers and antioxidant enzymes activity in tocopherol-deficient Arabidopsis thaliana plants. Ukr Biokhim Zhurn. 2012; 84(4): 41-48.

33. Goncharova EA. The Water status of cultivated plants and its diagnostics. St. Petersburg: Vavilov Res. Inst. Plant Industry, 2005. 112 p. (In Russian).

34. Bates LS, Walden RP, Tear GD. Rapid determination of free proline for water-stress studies. Plant Soil. 1973; 39(1): 205-207.

35. Zhao K, Fan H, Zhou S, Song J. Study on the salt and drought tolerance of Suaeda salsa and Kalanchoe claigremontiana under iso-osmotic salt and water stress. Plant Sci. 2003; 165(4): 837-844.

36. Kolupaev YuE, Yastreb TO, Oboznyi AI, Ryabchun NI, Kirichenko VV. Constitutive and cold-induced resistance of rye and wheat seedlings to oxidative stress. Russ $\mathrm{J}$ Plant Physiol. 2016; 63(3): 326-337.

37. Shlyk AA. Determination of chlorophylls and carotenoids in extracts of green leaves. In: Pavlinova OA. (ed) Biochemical Methods in Plant Physiology. Moscow: Nauka, 1971: 154170. (In Russian).

38. Munns R. Comparative physiology of salt and water stress. Plant Cell Environ. 2002; 25(2): 239-250.

39. Santos CV. Regulation of chlorophyll biosynthesis and degradation by salt stress in sunflower leaves. Sci Horticult. 2004; 103(1): 93-99.

40. Zhu L, Yang Z, Zeng X, Gao J, Liu J, Yi B, Ma C, Shen J, Tu J, Fu T, Wen J. Heme oxygenase 1 defects lead to reduced chlorophyll in Brassica napus. Plant Mol Biol. 2017; 93(6): 579-592.

41. Syvash OO, Zolotareva OK. Regulation of chlorophyll degradation in plant tissues. Biotechnologia Acta. 2017; 10(3): 20-30.

42. Kaya A, Doganlar ZB. Exogenous jasmonic acid induces stress tolerance in tobacco (Nicotiana tabacum) exposed to imazapic. Ecotoxicol Environ Saf. 2016; 124: 470-479.

43. Radchenko MP, Sychuk AM, Morderer YY. Decrease of the herbicide fenoxaprop phytotoxicity in drought conditions: the role 
of the antioxidant enzymatic system. $J$ Plant Protect Res. 2014; 54(4): 390-394.

44. Kolupaev YuE, Karpets YuV, Kabashnikova LF. Antioxidative system of plants: cellular compartmentalization, protective and signaling functions, mechanisms of regulation (Review). Appl Biochem Microbiol. 2019; 55(5): 441-459.

45. He H, He LF. Regulation of gaseous signaling molecules on proline metabolism in plants. Plant Cell Rep. 2018; 37(3): 387-392.
46. Sin'kevich MS, Deryabin AN, Trunova TI. Characteristics of oxidative stress in potato plants with modified carbohydrate metabolism. Russ J Plant Physiol. 2009; 56(2): 168-174.

47. Radyukina NL, Shashukova AV, Makarova SS, Kuznetsov VV. Exogenous proline modifies differential expression of superoxide dismutase genes in UV-B-irradiated Salvia officinalis plants. Russ J Plant Physiol. 2011; 58(1): 36-44. 